\title{
Medical care and manifestations of ageism in healthcare institutions: opinion of elderly people. The example of four countries
}

\author{
ANDREI SHPAKOU ${ }^{1, A-G}$, LUDMILA KLIMATCKAIA ${ }^{3, A-G}$, ALEH KUZNIATSOU 2, 6, B, E, F, \\ $\begin{array}{lll}\text { ORCID ID: 0000-0003-4340-5211 } & \text { ORCID ID: 0000-0001-8926-2901 } & \text { ORCID ID: 0000-0002-1348-8688 }\end{array}$ \\ SKAISTE LASKIENE ${ }^{4, A, ~ B}$, OLGA ZAITSEVA ${ }^{5, \text { B, D, E }}$ \\ ORCID ID: 0000-0002-0151-7736 ORCID ID: 0000-0001-7199-2308 \\ ${ }^{1}$ Department of Theory of Physical Culture and Sports Medicine, Yanka Kupala State University of Grodno, Grodno, \\ Belarus \\ ${ }^{2}$ Department of Microbiology, Immunology and Virology, Grodno State Medical University, Grodno, Belarus \\ ${ }^{3}$ Department of Social Pedagogy and Social Work, Krasnoyarsk State Pedagogical University named after V.P. Asta- \\ fiev, Krasnoyarsk, Russia \\ ${ }^{4}$ Department of Bioethics, Lithuanian University of Health Sciences, Kaunas, Lithuania \\ ${ }^{5}$ Department of Clinical Pathophysiology, Scientific Research Institute of the North Medical Problems, Siberian \\ Branch of the Russian Academy of Sciences, Krasnoyarsk, Russia \\ ${ }^{6}$ Faculty of General Medicine, School of Medical Science in Bialystok, Poland
}

A - Study Design, B - Data Collection, C - Statistical Analysis, D - Data Interpretation, E - Manuscript Preparation, F - Literature Search, G - Funds Collection

Summary Background. Population aging is a challenge for social policy and medical care. The problem of ageism - discrimination of a person by age - is closely connected with the phenomenon of the aging of society.

Objectives. The aim of this study was to investigate the views of $60+$ respondents about medical care and the possible manifestations of ageism in healthcare institutions in four countries for developing recommendations for the formation of "good practices" for older people and a worthy attitude towards them.

Material and methods. An anonymous survey was conducted on 478 people (who gave informed consent to participate in the study) aged 60+: in Belarus -139, Poland -110, Russia-123, Lithuania -106. Opinions about medical care and manifestations of ageism were assessed using a questionnaire by Kropińska entitled "Studying the phenomenon of age discrimination in older people".

Results. The opinion of the majority of respondents about medical care in their country of residence was found to be satisfactory. Manifestations of ageism in healthcare institutions, according to respondents, range from $20.9 \%$ to $43.0 \%$.

Conclusions.

In the analysed groups of respondents in four countries, the provision of medical care is assessed positively. The high level of manifestation of ageism in healthcare institutions is a problem, which indicates the need to reduce the risks of its occurrence.

Key words: aged, ageism, delivery of health care.

Shpakou A, Klimatckaia L, Kuzniatsou A, Laskiene S, Zaitseva O. Medical care and manifestations of ageism in healthcare institutions: opinion of elderly people. The example of four countries. Fam Med Prim Care Rev 2021; 23(1): 69-74, doi: https://doi.org/10.5114/ fmpcr.2021.103159.

\section{Background}

In the second half of the XX century, in the population of economically developed countries, due to the achievements of scientific, technical and social progress, demographic shifts took place, expressed by an increase in average life expectancy and an increase in the proportion of the elderly and senile population [1]. Throughout the past few decades, this process has become global and large-scale [2]. For example, the population over the age of 60 in Eastern Europe has doubled [3]. According to experts, by 2025 , there will be more than 800 million people over 65 in the world, which will make up $11 \%$ of the population. By 2050 , the share of elderly people may reach $22 \%$ of the world's population, and in the most developed regions, this may exceed $30 \%$ [4].

In this regard, as the population ages, for the economies of the countries of the Eastern European region, the growing pres- sure on the state budget and the aggravation of the need for medical care and social protection of the elderly are becoming a major problem [5]. The peculiarities of this problem are beginning to be actively investigated by psychologists, educators and physicians [6]. Political and socio-economic transformations taking place in the countries of Eastern Europe significantly change the social status of elderly people and the nature of their adaptation to emerging conditions [7], and reaching retirement age means a transition to a new stage of life - a relatively passive life - which often leads to a decrease in the quality of life $[8,9]$.

The aging processes themselves arise long before the legally established terms of retirement by age and are characterised by the degenerative-dystrophic changes in the cerebral cortex, followed by a decrease in cortical activity, which leads to the development of processes of inhibition of neuropsychic activity. This is manifested, in older people, by an increase in the length of time spent on processing incoming information, a deteriora- 
tion in short-term memory and rote memorisation, the development of emotional instability and exhaustion of neuropsychic processes, followed by a decrease in adaptive capabilities [10].

Despite the fact that the processes of adaptation to old age can begin long before actual retirement, they proceed for a long time and are often painful, both for the person himself and for his environment [11]. In addition, these processes are accompanied by a significant restructuring of consciousness in connection with a change in lifestyle, the intra-family climate, a decrease in vitality, which can lead to partial or complete dependence on other persons, and often to a more serious phenomenon - social insecurity, isolation and marginalisation [12]. Elderly people, in comparison with other categories of the population, have fewer opportunities to adapt to the prevailing socio-economic realities, since, due to age-related changes, they hardly develop a new dynamic stereotype, and their experience of life, acquired in a different socio-economic system, does not correspond to the new reality and the changed values of society [13].

Despite the efforts being made by healthcare institutions providing medical, psychological and social assistance to elderly patients in Eastern Europe, there are many unresolved problems. One of these is the level of provision of medical care and differences depending on the territorial unit, the degree of healthcare reform, which is expressed in the minimum number of geriatric doctors and specialised units of geriatric service [3, 14]. In addition, it should be borne in mind that the presence of an elderly patient in the clinic is accompanied by a change in the microclimate and is an important aspect. This can be considered by the patient as a manifestation of gerontological ageism [15]. Emerging unforeseen situations, a new environment, an unusual environment, unclear social status - these life circumstances force people to painfully adapt to the external environment [16].

Data from the Global World Values Survey (WHO, 2016) shows that negative attitudes towards older people (discrimination and gerontological ageism) are common, affecting the physical and mental health and quality of life. Thus, $60 \%$ of respondents from more than 83,000 people interviewed in 57 countries of the world reported that older people face disrespectful treatment and age discrimination [17].

Gerontological ageism is a type of discrimination including a disdainful attitude or degrading practices towards human dignity, implemented on the basis of negative age stereotyping [18, 19]. Ageism manifests itself in the willingness of society to perceive and cooperate only with those people who meet a certain "established criterion" of age.

An important task of public health is the development of medical care, the elimination of the phenomenon of age discrimination in society, as well as increasing the satisfaction of older people with medical services [20]. Medical specialists having contact with patients of older age groups need not only to have kindness, patience and endurance but also to develop them [21].

\section{Objectives}

The aim of this study was to investigate the views of $60+$ respondents about medical care and the possible manifestations of ageism in healthcare institutions in four countries for developing recommendations for the formation of "good practices" for older people and a worthy attitude towards them.

\section{Material and methods}

\section{Study location and respondents}

The study was conducted on a group of 478 people in age 60+ from Belarus (Grodno) - 139, Poland (Bialystok) - 110, Rus- sia (Krasnoyarsk) - 123, Lithuania (Kaunas) - 106. The criterion for the inclusion of individuals for participation in the study: permanent residence in their country, age 60+. Respondents aged 60+: university staff, students' relatives. They filled out an electronic questionnaire and described their experiences in healthcare institutions. The studies were conducted after informed consent was obtained. Those who did not agree to participate in the survey were excluded (in total, 22 elderly people). The research was approved by the bioethical commissions of partner universities.

\section{Collection of information}

The study was conducted in 2019-2020. The respondents were insured about the complete anonymity and voluntariness of participation in the survey, and they were informed about its goals and methodology. These studies were approved by the local ethics committee of the Scientific Research Institute of the North Medical Problems, Siberian Branch of the Russian Academy of Sciences, Krasnoyarsk, Russia.

\section{Data collection instruments}

Kropińska's questionnaire "Studying the phenomenon of age discrimination in older people" was used [22]. The questionnaire included 17 questions: determination of the characteristics of the socio-demographic situation of the respondents according to the criteria: gender, age, material status (self-esteem), education, family structure, place of residence; the opinion of respondents on the criterion for the provision of medical care (medical doctors, nursing); the opinion of respondents about the manifestations of gerontological ageism in healthcare institutions. Permission from the author of the questionnaire was obtained. The questionnaire was adapted to the research, taking into account the contingent being surveyed, and was translated from Polish into Russian and Lithuanian (semantic and textual plausibility, back translation).

\section{Statistical analysis}

Statistical data processing was carried out using the Statistica13PL software package. The correspondence of the obtained values to the law of normal distribution of the variational series was preliminarily evaluated. Due to the fact that the quantitative data had a distribution that differed from the norm, the methods of nonparametric statistics were used. The distribution of qualitative variables is presented as a percentage, and statistical comparisons were performed using independent chi-square analyses. The statistical significance level was set at $p<0.05$.

\section{Ethical considerations}

The Ethics Committee of Scientific Research Institute of the North Medical Problems, Siberian Branch of the Russian Academy of Sciences accepted the article (N6 8.06.2020).

\section{Results}

\section{Socio-demographic characteristics of respondents}

The socio-demographic characteristics of the respondents according to gender, age, marital status, financial well-being, education, family structure and residence are presented in Table 1.

Questionnaires were obtained from 153 men and 325 women, most of whom were married, some of them widowed or divorced, and only $7.7 \%$ were single/unmarried. The group was dominated by educated respondents of a middle financial situation. For the purposes of this analysis, only data from respondents' opinions on medical care and about the manifestation of ageism in healthcare institutions was included. 


\begin{tabular}{|c|c|c|c|c|c|c|}
\hline \multicolumn{2}{|l|}{ Main characteristics } & \multirow{2}{*}{$\begin{array}{l}\text { Belarus } n=139 \\
n(\%) \\
48(34.5)\end{array}$} & \multirow{2}{*}{$\begin{array}{l}\text { Russia } n=123 \\
n(\%) \\
34(27.6)\end{array}$} & \multirow{2}{*}{\begin{tabular}{|l} 
Lithuania $n=106$ \\
$n(\%)$
\end{tabular}} & \multirow{2}{*}{ 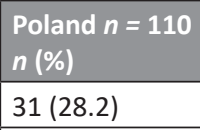 } & \multirow{2}{*}{$\begin{array}{l}\text { Total } n=478 \\
n(\%) \\
153(32.0)\end{array}$} \\
\hline Gender & male & & & & & \\
\hline & female & $91(65.5)$ & $89(72.4)$ & $66(62.3)$ & $79(71.8)$ & $325(68.0)$ \\
\hline \multirow[t]{3}{*}{ Age } & $60-69$ & $82(59.0)$ & $49(39.8)$ & $63(59.4)$ & $69(62.7)$ & $263(55.0)$ \\
\hline & $70-79$ & $46(33.1)$ & $48(39.0)$ & 40 (39.7) & $39(35.5)$ & $173(36.2)$ \\
\hline & $80+$ & $11(7.9)$ & $26(21.1)$ & $3(2.8)$ & $2(1.8)$ & $42(8.8)$ \\
\hline \multirow[t]{4}{*}{ Family status } & married & $53(38.1)$ & $37(30.1)$ & $45(42.5)$ & $52(47.3)$ & $187(39.1)$ \\
\hline & widower/widow & $48(34.5)$ & $68(55.3)$ & $26(24.5)$ & $33(30.0)$ & $175(36.6)$ \\
\hline & single/unmarried & 11 (7.9) & $12(9.8)$ & $9(8.5)$ & $5(4.5)$ & $37(7.7)$ \\
\hline & $\begin{array}{l}\text { divorce (living } \\
\text { separately) }\end{array}$ & $27(19.5)$ & $6(4.9)$ & $26(24.5)$ & $20(18.2)$ & $79(16.6)$ \\
\hline \multirow{5}{*}{$\begin{array}{l}\text { Financial situation } \\
\text { (self-esteem) }\end{array}$} & very good & $3(2.2)$ & $3(2.4)$ & $4(3.8)$ & $4(3.6)$ & $14(2.9)$ \\
\hline & good & $29(20.9)$ & $27(22.0)$ & $26(24.5)$ & 41 (36.9) & $123(25.7)$ \\
\hline & middle & $84(60.4)$ & 73 (59.3) & $71(67.0)$ & $57(51.4)$ & $285(59.6)$ \\
\hline & bad & $20(14.4)$ & $14(11.4)$ & $4(3.8)$ & $8(7.2)$ & $46(9.6)$ \\
\hline & very bad & $3(2.2)$ & $6(4.9)$ & $1(0.9)$ & $1(0.9)$ & $11(2.2)$ \\
\hline \multirow[t]{4}{*}{ Education } & higher & $46(33.1)$ & $25(20.3)$ & $43(40.6)$ & $37(33.3)$ & $151(31.6)$ \\
\hline & secondary & $25(18.0)$ & $25(20.3)$ & $16(15.1)$ & 44 (39.6) & $110(23.0)$ \\
\hline & vocational & $50(36.0)$ & 51 (41.5) & $47(44.3)$ & $28(26.2)$ & $176(36.8)$ \\
\hline & primary & $18(12.9)$ & 22 (17.9) & 0 & $1(0.9)$ & $41(8.6)$ \\
\hline \multirow[t]{3}{*}{ Family structure } & one generation & 71 (51.1) & 70 (56.9) & $51(48.1)$ & $38(34.2)$ & $230(48.1)$ \\
\hline & two generations & $42(30.2)$ & $27(22.0)$ & $46(43.4)$ & $50(45.0)$ & $165(34.5)$ \\
\hline & $\begin{array}{l}\text { three generations } \\
\text { or more }\end{array}$ & $26(18.7)$ & $26(21.1)$ & $9(8.5)$ & $22(20.8)$ & $83(17.4)$ \\
\hline
\end{tabular}

\begin{tabular}{|c|c|c|c|c|c|c|c|c|c|c|}
\hline \multirow{2}{*}{$\begin{array}{l}\text { Answers of } \\
\text { the respon- } \\
\text { dents }\end{array}$} & \multicolumn{2}{|l|}{ Belarus } & \multicolumn{2}{|l|}{ Russia } & \multicolumn{2}{|l|}{ Lithuania } & \multicolumn{2}{|l|}{ Poland } & \multicolumn{2}{|l|}{ Total } \\
\hline & 1 & 2 & 1 & 2 & 1 & 2 & 1 & 2 & 1 & 2 \\
\hline Very well & $1(0.9)$ & 0 & $2(1.8)$ & $2(1.7)$ & $2(2.2)$ & $2(2.8)$ & $2(2.3)$ & $1(1.4)$ & $7(1.7)$ & $5(1.3)$ \\
\hline Good & $33(28.7)$ & 44 (38.9) & $32(27.8)$ & $32(26.7)$ & $19(20.4)$ & $10(13.9)$ & $15(17.4)$ & 9 (12.5) & $99(24.2)$ & $95(25.2)$ \\
\hline Rather good & $54(47.0)$ & $42(37.2)$ & $44(38.3)$ & $51(42.5)$ & $24(25.8)$ & $14(19.4)$ & $28(32.6)$ & $31(43.1)$ & $150(36.7)$ & $138(36.6)$ \\
\hline Rather bad & $22(19.1)$ & $22(19.5)$ & $32(27.8)$ & $26(21.7)$ & 34 (36.6) & 25 (34.7) & $32(37.0)$ & $22(30.6)$ & $120(29.3)$ & $95(25.3)$ \\
\hline Bad & $5(4.3)$ & $5(4.4)$ & $5(4.3)$ & $9(7.4)$ & $14(15.0)$ & $21(29.2)$ & $9(10.7)$ & $9(12.4)$ & $33(8.1)$ & 44 (11.6) \\
\hline Total answers & 115 & 113 & 115 & 120 & 93 & 72 & 86 & 72 & 409 & 377 \\
\hline
\end{tabular}

1 - medical doctor care, 2 - nursing care.

\section{Respondents' opinions on medical care}

Analysis of the data made it possible to establish differences in the opinions of respondents from different countries according to the criterion: medical care. Among the answers of the respondents from Belarus and Russia, the answers "good" and "rather good" prevailed. The answers "rather bad" and "bad" were more often given by respondents from Lithuania and Poland (Table 2).

Answers of "good" and "rather good" by older people prevailed among respondents in Belarus and Russia in comparison with data from Lithuania and Poland $(p<0.05)$.

\section{Opinions of respondents about the manifestation of ageism in healthcare institutions}

According to respondents from Poland, the proportion of elderly people who experienced manifestations of gerontological ageism was $20.9 \%$. The data for Belarus and Lithuania was very similar: $26.6 \%$ and $26.3 \%$, respectively. The highest indicator of age discrimination in healthcare institutions was established by the respondents in Russia - 30.9\%. No statistically significant relationship between the country of interview and manifestations of age discrimination in older people was established $(p>0.1)$.

An assessment of the signs of gerontological ageism in healthcare institutions was carried out: significant differences were established between the country of questioning and the frequency of discrimination by medical personnel. In most cases, the manifestation of discrimination was observed on the part of a doctor $(p<0.05)$, a nurse $(p<0.05)$ and receptionists $(p<0.05)$. The profession of a doctor was mentioned by Polish respondents in $50 \%$ of cases. Manifestations of discrimination on the part of nurses were noted in $50 \%$ of cases by respondents from Russia, $35 \%$ from Poland and 15\% from Lithuania and Belarus.

Statistically significant differences were found among the departments of clinics $(p<0.05)$ and admission wards $(p<0.05)$ as places where elements of gerontological ageism are manifested. For example, in Lithuania, $50 \%$ of the respondents pointed to the manifestations of ageism upon admission to the emergency room (42.9\%) but excluded the clinic's departments from this list. $40 \%$ of the respondents in Poland, as a place of discrimination on the basis of age, pointed to the admission ward of the hospital. 


\begin{tabular}{|c|c|c|c|c|c|}
\hline \multirow{2}{*}{$\begin{array}{l}\text { Respondents' answers to } \\
\text { the question }\end{array}$} & \multicolumn{4}{|l|}{ Country } & \multirow{2}{*}{$\begin{array}{l}\text { Total } \\
n=478\end{array}$} \\
\hline & $\begin{array}{l}\text { Belarus } \\
n=139 \\
\end{array}$ & $\begin{array}{l}\text { Russia } \\
n=123\end{array}$ & $\begin{array}{l}\text { Lithuania } \\
n=106\end{array}$ & $\begin{array}{l}\text { Poland } \\
n=110\end{array}$ & \\
\hline \multicolumn{6}{|c|}{ Have you ever witnessed discrimination against an older person? } \\
\hline Yes & $\begin{array}{l}36(25.9) \\
(18.6-33.2)\end{array}$ & $\begin{array}{l}42(34.2) \\
(25.8-42.5)^{*}\end{array}$ & $\begin{array}{l}28(26.4) \\
(18.0-34.8)\end{array}$ & $\begin{array}{l}26(23.6) \\
(15.7-31.6)\end{array}$ & $\begin{array}{l}132(26.4) \\
(23.6-31.6)\end{array}$ \\
\hline No & $\begin{array}{l}103(74.1) \\
(66.8-81.4)\end{array}$ & $\begin{array}{l}81(65.8) \\
(57.5-74.2)\end{array}$ & $\begin{array}{l}78(73.6) \\
(65.2-82.0)\end{array}$ & \begin{tabular}{|l|}
$84(76.4)$ \\
$(66.4-84.3)$
\end{tabular} & $\begin{array}{l}346(73.6) \\
(68.4-78.4) \\
\end{array}$ \\
\hline \multicolumn{6}{|c|}{ Do you think the phenomenon of age discrimination against older people in the health sector is a social problem? } \\
\hline Yes & $\begin{array}{l}73(52.5) \\
(44.2-60.8)\end{array}$ & \begin{tabular}{|l|}
$81(65.8)$ \\
$(57.5-74.2)$ \\
\end{tabular} & \begin{tabular}{|l|}
$53(50.0)$ \\
$(40.5-59.5)$
\end{tabular} & \begin{tabular}{|l|}
$44(40.0)$ \\
$(30.8-49.2)$
\end{tabular} & $\begin{array}{l}251(52.5) \\
(48.0-57.0)\end{array}$ \\
\hline No & $\begin{array}{l}66(47.5) \\
(39.5-55.8)\end{array}$ & $\begin{array}{l}42(34.2) \\
(25.8-42.5)^{*}\end{array}$ & $\begin{array}{l}53(50.0) \\
(40.5-59.5)\end{array}$ & $\begin{array}{l}66(60.0) \\
(50.8-69.2)\end{array}$ & $\begin{array}{l}227(47.5) \\
(43.0-52.0)\end{array}$ \\
\hline \multicolumn{6}{|c|}{ Did the doctor explain some of the symptoms of the disease by the phenomenon of old age? } \\
\hline Yes & $\begin{array}{l}66(47.5) \\
(39.5-55.8)\end{array}$ & \begin{tabular}{|l}
$74(60.2)$ \\
$(51.5-68.8)$
\end{tabular} & \begin{tabular}{|l|}
$75(70.8)$ \\
$(62.1-79.4)^{*}$
\end{tabular} & \begin{tabular}{|l|}
$62(56.4)$ \\
$(47.1-65.6)$
\end{tabular} & $\begin{array}{l}215(58.4) \\
(40.5-49.4) \\
\end{array}$ \\
\hline No & $\begin{array}{l}73(52.5) \\
(44.2-60.8)\end{array}$ & $\begin{array}{l}49(39.8) \\
(31.2-48.5)\end{array}$ & $\begin{array}{l}31(29.2) \\
(20.6-37.9)\end{array}$ & $\begin{array}{l}48(43.6) \\
(34.4-52.9)\end{array}$ & $\begin{array}{l}153(41.6) \\
(27.8-36.2)\end{array}$ \\
\hline
\end{tabular}

* Significant differentiation at $p<0.05\left(\mathrm{chi}^{2}\right)$ for the designated group (in comparison with other groups).

Respondents from Belarus and Russia described manifestations of age discrimination in the admission ward $(23.5 \%$ and $29.0 \%$, respectively) and clinic departments (18.0\% and $21.6 \%$ ).

The number of persons who indicated the presence of discrimination against them at the reception of the district (family) doctor was the same in all countries. Analysing the reasons for ageism, it was noted that Polish respondents pointed to a form of discrimination as a refusal to hospitalise (30.4\%). Lithuanian respondents never faced such a problem. The most common was the dismissive attitude towards elderly patients on the part of the medical staff of polyclinics in Belarus, Russia and Lithuania: $51.4 \%, 41.2 \%$ and $28.6 \%$, respectively. Interestingly, $30 \%$ of the respondents indicated that medical personnel were unwilling to provide objective information about their medical history.

Assessment of age discrimination in medical institutions in relation to other elderly people by respondents aged $60+$ showed significant differences in responses in different countries. A high rate of the frequency of such cases was recorded among respondents in Russia, and a low rate was recorded among respondents in Poland $(p<0.02)$ (Table 3 ).

The phenomenon of discrimination of older people by age in healthcare institutions is a social problem, which was the opinion of $50 \%$ of the respondents in Belarus, Lithuania and Russia, and $40 \%$ of the respondents in Poland agree with this statement. In all groups, more than half of the respondents (Lithuania $-70.8 \%$, Belarus $-47.5 \%$ ) confirmed that the medical doctor explained the symptoms of the disease by the onset of old age.

\section{Discussion}

In modern scientific literature, there are many publications on the status and assessment of medical care for elderly patients, though not always taking into account local characteristics, which indicates the need for research in this area [5-7, 18, 19].

The explanation by medical specialists of the manifestation of disease symptoms by the onset of old age is the result of insufficient coverage of geriatric problems in the training of health professionals. The study showed that for $50 \%$ of respondents in all countries, the doctor explained the presence of specific symptoms of diseases by the onset of old age. A study by Jędrzejkiewicz et al. [23] described similar situations: a study in which $50 \%$ of people aged $60+$ heard from a doctor that old age is the cause of health problems. In the study by Kropińska [22], $22 \%$ of the elderly indicated that the doctor explained the pres- ence of symptoms of diseases by old age. In a study by Palmore (author of the ageism scale) in 2001, it was shown that the manifestation of elements of age discrimination and symptoms of the disease in the elderly are associated with age-related changes (24\% of cases) [24]. The phenomenon of ageism in Canada and the United States is different: the elderly citizens of these countries confirmed references to age when symptoms of a disease appeared in $16 \%$ and $22 \%$ of cases. In later studies by McGuire et al. [25], it was shown that $40 \%$ of people aged $60+$ claimed that the medical staff explained the onset of symptoms of a disease by reaching old age. Research conducted by Saleem et al. [26] on a group of 380 patients aged $65+$ showed that disappointment on the part of the elderly was caused by the unwillingness of medical personnel to provide and explain detailed information about their health status (60\%).

The data received by them confirm that in $30 \%$ of cases, the medical personnel did not want to clearly explain the mechanism of the development of the pathology, and the patient's expectations of obtaining qualified information remain unfulfilled.

A study by Grzanka-Tykwińska et al. [27] showed that $16 \%$ of respondents aged $60+$ informed that they were victims of other manifestations of discrimination due to age. In our study, the proportion of older people who perceived the actions of medical personnel as discriminatory was $25 \%$. The prevalence of elements of gerontological ageism in healthcare institutions was noted by respondents in Russia (30.9\%) and in Poland (20.9\%).

In studies on large samples of people aged $50+$ and $60+$, it was shown that, on average, every sixth respondent reported that he felt elements of age discrimination on the part of medical personnel in such forms as: refusal to perform additional diagnostic tests and procedures, neglect and ridicule by medical workers or even a refusal to provide qualified medical care [28].

According to a number of studies, discrimination against the elderly by the actions of a doctor was $75 \%$ (research by Kropińska) and $23 \%$ by a nurse. Inpatient departments were named as a place of discrimination (44.2\%). Analysis of the respondents' answers in our study showed that the most frequent "discriminators" were the doctor and the nurse $(34.1 \%$ and $23.8 \%$, respectively). Thus, our study showed discrimination against older people because of their age in healthcare institutions, which is confirmed by studies in recent years, where $20 \%$ of respondents noted similar trends $[15,16] .25 \%$ of respondents in Lithuania, Poland and Belarus, as well as among 35\% of respondents in Russia, noted elements of ageism in the behaviour of medical specialists. 
The frequency of occurrence of discrimination against other elderly people is identical to the frequency of occurrence of elements of discrimination in relation to the respondents themselves, which indicates a readiness to publicly admit the existence of a discriminatory attitude and exacerbates this problem in society. The results are new. In earlier studies, older people were reluctant to admit that they were discriminated against: $13 \%$ of the respondents experienced manifestations of ageism, while the rest tried to hide it $[29,30]$. Our research has shown the presence of a high percentage of respondents (50\%) who consider the phenomenon of discrimination against the elderly in the healthcare system as a social problem (the maximum indicator was $65.9 \%$ in Russia).

Studies in recent years have shown that $70.2 \%$ assess the level of organisation of nursing care in their countries as sufficient [30]. In our study, the number of respondents who rate the organisation of nursing care as sufficient was $60 \%$ of those aged $60+$.

In the study by Saleem et al., $64.5 \%$ of patients were completely satisfied with the provided health services and the level of care provided by medical personnel [26]. We have confirmed a high assessment of the medical services provided to people $60+$, but in $50 \%$ of the responses, a disdainful attitude was noted, which is considered as a problem of modern geriatrics. Respondents in Russia and Belarus showed a high level of medical care in their countries but also indicated the manifestation of gerontological ageism in relation to them in healthcare institutions.

The authors of a number of scientific publications on overcoming ageism in medical institutions negatively assessed the current system of medical care [13, 29-31]. It is recommended to conduct work in the following areas: educating the elderly in the elements of manifestation of gerontological ageism; work with the population to improve gerontological culture; work with medical workers to increase gerontological competence, including ageism; organisation in healthcare institutions of a system for monitoring the quality of service for the elderly; providing older people with complete and reliable information about the possibilities of solving their problems; social services; developing care schemes and types of assistance for older people to enable them to live independently.

\section{Limitations of the study}

In the analysis of the results, it is necessary to take into account of respondents' opinions not only on medical care but specifically gerontological care with the significant difference in the age of the patients. Perhaps these age differences could have some impact on the results of the study. This direction will be a continuation of this work.

\section{Conclusions}

In the analysed groups of respondents in four countries, the provision of medical care was assessed positively. The high level of ageism manifestation in health care institutions is a problem, which indicates the need to reduce the risks of its occurrence. In the process of providing medical care, elements of its transformation should be envisaged to increase patient satisfaction with medical services and reduce the frequency of manifestations of gerontological ageism. For the formation of "good practices" in the medical care of the elderly, the inclusion of geriatric issues in training and advanced training programmes for general practitioners and nurses is recommended.

Source of funding: This work and paper were supported by project RFBR N 20-513-00002Bel_a (BRFFR-RFBR M20P-006). Conflicts of interest: The authors declare no conflicts of interest.

\section{References}

1. Cosco TD, Howse K, Brayne C. Healthy ageing, resilience and wellbeing. Epidemiol Psychiatr Sci 2017; 26(6): 579-583, doi: 10.1017/ S2045796017000324.

2. Campisi J, Kapahi P, Lithgow GJ, et al. From discoveries in ageing research to therapeutics for healthy ageing. Nature 2019; 571(7764): 183-192, doi: 10.1038/s41586-019-1365-2.

3. Cybulski M. Proces starzenia się społeczeństwa istotnym problemem zdrowia publicznego. Opieka nad osobami starszymi. Przewodnik dla zespołu terapeutycznego. Warszawa: Wydawnictwo PZWL; 2016: 11-16 (in Polish).

4. Kanasi E, Ayilavarapu S, Jones J. The aging population: demographics and the biology of aging. Periodontol 2000 2016; 72(1): 13-18, doi: $\operatorname{org} / 10.1111 /$ prd.12126.

5. Strizhitskaya O. Aging in Russia. Gerontologist 2016; 56(5): 795-799, doi: org/10.1093/geront/gnw007.

6. Antipova SI, Antipov VV, Savina II. [Problems of elderly people of Belarus in the light of medical statistics]. International reviews: Clinical Practice and Health 2017; 5-6: 75-92 (in Russian).

7. Hurria A, Carpenter CR, McFarland F, et al. Models and studies of aging: executive summary of a report from the U13 Conference Series. J Am Geriatr Soc 2019; 67(3): 428-433, doi: org/10.1111/jgs.15788.

8. Vanleerberghe P, De Witte N, Claes C, et al. The quality of life of older people aging in place: a literature review. Qual Life Res 2017; 26(11): 2899-2907, doi: 10.1007/s11136-017-1651-0.

9. Vauclair CM, Lima ML, Abrams D, et al. Older people think that others think of them, and does it matter? The role of meta-perceptions and social norms in the prediction of perceived age discrimination. Psychology and Aging 2016; 31(7): 699-710, doi: 10.1037/ pag0000125.

10. Netten A, Trukeschitz B, Beadle-Brown J, et al. Quality of life outcomes for residents and quality ratings of care homes: is there a relationship? Age Ageing 2012; 41: 512-517, doi: 10.1093/ageing/afs050.

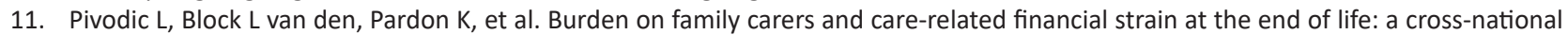
population-based study. Eur J Publ H 2014; 24: 819-826, doi: 10.1093/eurpub/cku026.

12. Lamont RA, Swift HJ, Abrams D. A review and meta-analysis of age-based stereotype threat: negative stereotypes, not facts, do the damage. Psychol Aging 2015; 30(1): 180-193, doi: 10.1037/a0038586.

13. Burnes D, Sheppard C, Henderson CR Jr, et al. Interventions to reduce ageism against older adults: a systematic review and metaanalysis. Am J Public Health 2019; 109(8): e1-e9, doi: 10.2105/AJPH.2019.305123.

14. Romaniuk P, Szromek AR. The evolution of the health system outcomes in Central and Eastern Europe and their association with social, economic and political factors: an analysis of 25 years of transition. BMC Health Serv Res 2016; 16: 95, doi: org/10.1186/s12913-0161344-3.

15. Senger E. Ageism in medicine a pressing problem. CMAJ 2019; 191(2): E55-E56, doi: 10.1503/cmaj.109-5698.

16. Dobrowolska B, Jędrzejkiewicz B, Pilewska-Kozak A, et al. Age discrimination in healthcare institutions perceived by seniors and students. Nurs Ethics 2019; 26(2): 443-459, doi: 10.1177/0969733017718392. 
17. WHO. Multisectoral action for a life course approach to healthy ageing: draft global strategy and plan of action on ageing and health. Document A69/17. Geneva: WHO; 2016.

18. Kydd A, Fleming A. Ageism and age discrimination in health care: fact or fiction? A narrative review of the literature. Maturitas 2015; 81: 432-438, doi: 10.1016/j.maturitas.2015.05.002.

19. Harris K, Krygsman S, Waschenko J, et al. Ageism and the older worker: a scoping review. Gerontologist 2018; 58(2): e1-e14, doi: 10.1093/geront/gnw194.

20. White F. Primary health care and public health: foundations of universal health systems. Med Princ Pract 2015; 24(2): 103-116, doi: $10.1159 / 000370197$.

21. Kagan SH, Melendez-Torres GJ. Ageism in nursing. J Nurs Manag 2015; 23(5): 644-650, doi: 10.1111/jonm.12191.

22. Kropińska S. Dyskryminacja osób starszych ze względu na wiek w polskim systemie ochrony zdrowia. Poznań: Uniwersytet Medyczny im. K. Marcinkowskiego w Poznaniu; 2013 (in Polish).

23. Jędrzejkiewicz B, Dobrowolska B, Kaučič B. Wybrane aspekty opieki geriatrycznej w opinii osób starszych oraz studentów medycyny i pielęgniarstwa w kontekście dyskusji na temat ageizmu w sektorze opieki zdrowotnej. Gerontol Pol 2015; 23(4): 165-171 (in Polish).

24. Palmore E. Ageism in Canada and the United States. J Cross Cult Gerontol 2004; 19(1): 41-46, doi: 10.1023/b:jccg.0000015098.62691. ab.

25. McGuire SL, Klein DA, Chen SL. Ageism revisited: a study measuring ageism in East Tennessee, USA. Nurs Health Sci 2008; 10(1): 11-16, doi: 10.1111/j.1442-2018.2007.00336.x.

26. Saleem T, Khalid U, Qidwai W. Geriatric patients' expectations of their physicians: findings from a tertiary care hospital in Pakistan. BMC Health Serv Res 2009; 9: 205, doi: org/10.1186/1472-6963-9-205.

27. Grzanka-Tykwińska A, Rzepka A, Chudzińska M, et al. Problematyka przemocy wobec osób starszych. Now Lek 2012; 81(1): 44-48 (in Polish).

28. Wagenaar DB, Rosenbaum R, Page C, et al. Primary care physicians and elder abuse: current attitudes and practices. J Am Osteopath Assoc 2010; 110(12): 703-711.

29. Rynkowska D. Przemoc wobec osób starszych - sposoby przeciwdziałania. Polityka i Społeczeństwo 2019; 1(17): 69 -82 (in Polish).

30. Wróblewska I, Sobik-Niemczynowska B, Błaszczuk J, et al. Opinia pacjentów na temat trudności wieku podeszłego oraz roli opieki pielęgniarskiej w kształtowaniu zachowań proaktywnych u osób w wieku podeszłym. Fam Med Prim Care Rev 2014; 16(4): 356-359 (in Polish).

31. de São José JMS, Amado CAF. On studying ageism in long-term care: a systematic review of the literature. Int Psychogeriatr 2017; 29(3): 373-387, doi: 10.1017/S1041610216001915.

Tables: 3

Figures: 0

References: 31

Received: 16.09 .2020

Reviewed: 28.09 .2020

Accepted: 2.11 .2020

Address for correspondence:

Andrei Shpakou, MD, PhD, Assoc. Prof.

Department of Theory of Physical Culture and Sports Medicine

Yanka Kupala State University of Grodno

st. Ozheshko 22

230023 Grodno

Belarus

Tel.: +375 297831034

E-mail:shpakofff@tut.by 